\title{
Pengaruh Dividend Per Share, Earning Per Share, Price Earning Ratio terhadap Harga Saham pada Perusahaan Manufaktur Non-BUMN yang Terdaftar di Bursa Efek Indonesia
}

\author{
*Steffany Fernando Putra, Haryono, Susi Tri Wahyuni \\ Fakultas Ekonomi dan Bisnis Universitas Bhayangkara Surabaya, Indonesia
}

DOI: 10.46821/bharanomics.v2i1.195

\begin{abstract}
Abstrak
Penelitian ini bertujuan untuk untuk mengetahui dan menguji pengaruh Pengaruh Dividend Per Share, Earning Per Share, Price Earning Ratio Terhadap Harga Saham Pada Perusahaan Manufaktur non-BUMN yang Terdaftar di Bursa Efek Indonesia. Penelitian ini merupakan penelitian kuantitatif dengan menggunakan data sekunder berupa laporan keuangan tahunan. Perusahaan yang dijadikan sampel pada penelitian ini adalah perusahaan manufaktur non-BUMN yang terdaftar di Bursa Efek Indonesia. Teknik yang digunakan adalah purposive sampling.Penelitian ini menggunakan teknik regresi data panel, uji t untuk menguji pengaruh secara parsial. Variabel bebas dalam penelitian ini terdari dari Dividend Per Share (X1), Earning Per Share (X2), Price Earning Ratio (X3), sedangkan untuk variabel terikat yaitu Harga Saham (Y).Hasil penelitian ini menunjukkan Dividend Per Share (DPS) berpengaruh signifikan terhadap harga saham pada perusahaan manufaktur non BUMN yang terdaftar di Bursa Efek Indonesia, Earning Per Share (EPS) berpengaruh signifikan terhadap harga saham pada perusahaan manufaktur non BUMN yang terdaftar di Bursa Efek Indonesia, Price Earning Ratio (PER) tidak berpengaruh signifikan terhadap harga saham pada perusahaan manufaktur non BUMN yang terdaftar di Bursa Efek Indonesia, Diantara variabel Dividend Per Share (DPS), Earning Per Share (EPS) dan Price Earning Ratio (PER), variabel Earning Per Share (EPS) yang berpengaruh dominan terhadap harga saham pada perusahaan manufaktur non BUMN yang terdaftar di Bursa Efek Indonesia.
\end{abstract}

Kata Kunci: Dividend Per Share, Earning Per Share, Price Earning Ratio dan Harga Saham.

\begin{abstract}
:
This study aims to determine and examine the effect of dividend per share, earnings per share, price earnings ratio on stock prices in non-state-owned manufacturing companies listed on the Indonesia Stock Exchange. This research is a quantitative research using secondary data in the form of annual financial reports. The sample companies in this study are non-BUMN manufacturing companies listed on the Indonesia Stock Exchange. The technique used is purposive sampling.This research uses panel data regression technique, t test to partially test the effect. The independent variables in this study consist of Dividend Per Share (X1), Earning Per Share (X2), Price Earning Ratio (X3), while the dependent variable is Stock Price (Y).The results of this study indicate that Dividend Per Share (DPS) has a significant effect on stock prices in non-BUMN manufacturing companies listed on the Indonesia Stock Exchange, Earning Per Share (EPS) has a significant effect on stock prices in non-BUMN manufacturing companies listed on the Indonesia Stock Exchange, Price Earning Ratio (PER) has no significant effect on stock prices in non-BUMN manufacturing companies listed on the Indonesia Stock Exchange, among the variables Dividend Per Share (DPS), Earning Per Share (EPS) and Price Earning Ratio (PER), the variable Earning Per Share Share (EPS) which has a dominant effect on stock prices in non-BUMN manufacturing companies listed on the Indonesia Stock Exchange.
\end{abstract}

Keywords: Dividend Per Share, Earning Per Share, Price Earning Ratio and Stock Price. 


\section{PENDAHULUAN}

Sejalan dengan berkembangnya perekonomian, banyak perusahaan yang melakukan ekspansi usaha yaitu ditandai dengan berkembang pesatnya perusahaan yang terdaftar di Bursa Efek Indonesia salah satunya perusahaan manufaktur non BUMN. Perusahaan manufaktur merupakan perusahaan yang memproduksi sendiri barang - barang, yang selanjutnya barang-barang yang telah selesai diproduksi lalu dijual. Dalam menghadapi persaingan, perusahaan harus berupaya mempertahankan dan meningkatkan kinerja perusahaan sebagai upaya menjaga kelangsungan usahanya. Pada umumnya perusahaan manufaktur di Indonesia dalam era globalisasi selayaknya berusaha untuk memproduksi barang berkualitas tinggi dengan penekanan biaya (minimum) dalam rangka meningkatkan daya saing baik dipasar domestik maupun pasar global.Tujuan utama dari investor dalam berinvestasi adalah untuk memperoleh imbalan atas investasinya, berupa dividen atau keuntungan, yaitu selisih antara harga pasar saham dengan harga nominalnya. Selanjutnya tujuan perusahaan menerima investasi tersebut adalah untuk memperoleh hasil yang diharapkan, walau ada kemingkinan dihadapinya resiko (Sanjaya dan Afriyenis, 2018). Faktor yang mempengaruhi ekspetasi harga saham yang biasanya dipertimbangkan oleh investor yaitu kinerja fundamental keuangan perusahaan untuk menghasilkan laba. Investor harus jeli terhadap kemampuan fundamental perusahaan untuk meningkatkan laba yang merupakan factor penting dalam pembuatan keputisan strategic perusahaan ke depannya (Sanjaya dan Afriyenis, 2018).Harga saham merupakan faktor yang sangat penting unutk diperhatikan dan indikator digunakan untuk mengukur kesejahteraan pemegang saham. Semakin banyak orang yang membeli saham maka harga saham cenderung bergerak naik dan sebaliknya semakin banyak orang yang menjual sahamnya makan harga saham cenderung bergerak turun. Jika harga saham meningkat maka kekayaan pemegang saham juga akan meningkat, begitu juga sebaliknya jika harga saham mengalami penurunan maka kekayaan pemegang saham juga akan mengalami penurunan (Rahmadewi dan Abudanti, 2018).

\section{TINJAUAN PUSTAKA \\ Harga Saham}

Harga saham merupakan harga yang terjadi di bursa pada waktu tertentu. Harga saham bisa berubah naik ataupun turun dalam hitungan waktu yang begitu cepat. Pergerakan harga saham tersebut ditentukan oleh permintaan dan penawaran atas saham-saham (Junaeni, 2020). Dalam sebuah pasar modal harga saham bisa berubah sewaktu-waktu dan ini tergantung pada informasi yang ada. Pesaingan antara penjual dan pembeli di Bursa Efek Indonesia akan menyebabkan timbulnya harga keseimbangan atau yang biasa disebut nilai pasar.

\section{Pasar Modal}

Pasar modal adalah pasar yang memperjualbelikan surat-surat berharga seperti saham, sertifikat saham, dan obligasi dimana tujuannya adalah untuk memenuhi kebutuhan modal untuk meningkatkan usaha dengan menjual sahamnya pada para investor (Putra, 2018). Keadaan pasar modal sebagai langkah bagi investor untuk memutuskan membeli saham. Informasi yang ada di pasar modal mempengaruhi kepercayaan investor yang membentuk efisiensi pasar modal. Kenaikan dan 
penurunan volume transaksi dan indeks harga saham menunjukkan kepercayaan investor untuk melakukan transaksi di Bursa Efek Indonesia (Putra, 2018).

\section{Dividend Per Share (DPS)}

Dividend Per Share (DPS) merupakan laba per lembar saham yang dibagikan kepada sejumlah saham biasa yang beredar dan dipegang oleh para pemegang saham, dimana deviden tersebut dapat dibagikan dalam bentuk surat hutang, kas, aktiva dan saham. Dividend Per Share (DPS) ini berguna bagi investor untuk menunjukkan prospek perusahaan yang menjual sahamnya dimasa yang akan datang (Reke, 2020). Perusahaan dengan Dividend Per Share (DPS) yang lebih tinggi akan lebih diminati investor karena investor akan memiliki kepastian tentang modal investasinya. Perusahaan juga perlu memperhatikan kebutuhan investasinya, sehingga perusahaan perlu menetapkan kebijakan deviden terkait permbayaran pemegang saham, sebagai investasinya perusahaan atau menggunakan dividen yang dibutuhkan di perusahaan (Tiara dkk., 2020).Tujuan investor membeli sejumlah saham dengan harapan memperoleh keuntungan dari kenaikan harga saham ataupun sejumlah dividen di masa yang akan datang. Oleh karena itu,kenaikan dividen merupakan hal positif yang akan menaikkan ekspektasi mereka mengenai pendapatan perusahaan. Hal ini juga akan berdampak pada harga saham yang juga akan mengalami kenaikan akibat kenaikan deviden (Putra, 2018).

\section{Earning Per Share (EPS)}

Earning Per Share (EPS) menunjukan laba untuk setiap lembar saham. Naik dan turunnya laba perlembar saham dari tahun ke tahun menjadi berita sangat penting dalam mengetahui tinggi ataupun rendahnya kinerja manajemen. Perusahaan dapat memberikan keuntungan yang tinggi kepada pemegang saham ditandai dengan tingginya laba perlembar saham, sebaliknya jika laba perlembar saham yang dihasilkan lebih rendah, maka perusahaan dapat memberikan tingkat keuntungan yang rendah (Rahmadewi dan Abundanti, 2018). Seorang investor yang ingin berinvestasi tidak hanya melihat pada struktur modal, perlu juga melihat Earning Per Share (EPS) karena Earning Per Share (EPS) merupakan gambaran mengenai kemampuan perusahaan dalam menghasilkan keuntungan bersih dalam setiap lembar saham. Earning Per Share (EPS) mempunyai pengaruh kuat terhadap harga saham, ketika Earning Per Share (EPS) meningkat maka harga saham ikut meningkat (Arifian dan Hardi, 2017).

\section{Price Earning Ratio (PER)}

Price Earning Ratio (PER) merupakan rasio penilaian yang menggambarkan apresiasi pasar terhadap kemampuan perusahaan dalam menghasilkan laba, Price Earning Ratio (PER) memberikan indikasi tentang jangka yang diperlukan diperlukan untuk mengembalikan dana pada tingkat harga saham dan keuntungan suatu perusahaan pada periode tertentu (Martha dan Meilin, 2018). Rasio ini sering digunakan untuk membandingkan peluang investasi. Suatu perusahaan yang memiliki Price Earning Ratio (PER) yang tinggi, berarti perusahaan tersebut mempunyai tingkat pertumbuhan yang tinggi hal ini menunjukan bahwa pasar mengharapkan pertumbuhan laba dimasa mendatang, sebaliknya perusahaan dengan Price Earning Ratio (PER) rendah akan mempunyai tingkat pertumbuhan yang rendah, semakin rendah Price Earning Ratio (PER) suatu 
saham maka semakin baik atau murah harga untuk diinvestasikan (Desiana, 2017).

\section{Hipotesis}

1. Bahwa Devidend Per Share (DPS)berpengaruh secara signifikan terhadap harga saham pada perusahaan manufaktur non BUMN yang terdaftar di Bursa Efek Indonesia.

2. Bahwa Earning Per Share (EPS) berpengaruh secara signifikan terhadap harga saham pada perusahaan manufaktur non BUMN yang terdaftar di Bursa Efek Indonesia.

3. Bahwa Price Earning Ratio (PER) berpengaruh secara signifikan terhadap harga saham pada perusahaan manufaktur non BUMN yang terdaftar di Bursa Efek Indonesia.

4. Bahwa Devidend Per Share (DPS), Earning Per Share (EPS), Price Earning Ratio (PER) berpengaruh secara dominan terhadap harga saham pada perusahaan manufaktur non BUMN yang terdaftar di Bursa Efek Indonesia.

\section{METODE PENELITIAN}

\section{Lokasi dan Waktu Penelitian}

Lokasi dari objek penelitian ini adalah perusahaan manufaktur non BUMN yang terdaftar di Bursa Efek Indonesia. Penelitian dilakukan pada bulan November 2020 sehingga data yang diperlukan adalah laporan Dividend Per Share, Earning Per Share dan Price Earning Ratio. Objek yang diteliti adalah perusahaan manufaktur non BUMN yang terdaftar di Bursa Efek Indonesia.

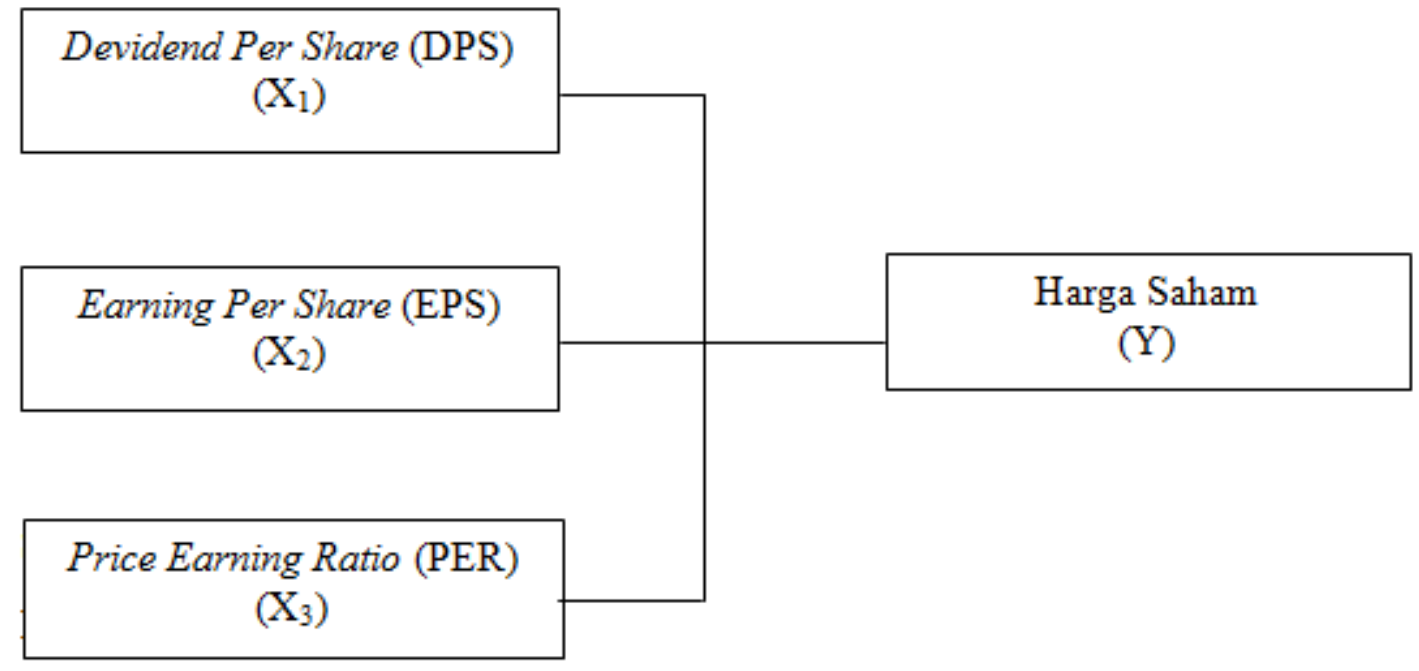

Gambar 1

Kerangka Konseptual

Keterangan:

$\mathrm{X}_{1}=$ Devidend Per Share (DPS)

$\mathrm{X}_{2}=$ Earning Per Share (EPS)

$\mathrm{X}_{3}=$ Price Earning Ratio (PER)

$\mathrm{Y}=$ Harga Saham 


\section{Pendekatan Penelitian}

Pendekatan penelitian dilakukan dengan pendekatan kuantitatif.

\section{Metode Pengumpulan Data}

Metode pengumpulan data dalam penelitian ini yaitu metode dokumentasi. Dokumentasi dilakukan dengan mengumpulkan data sekunder berupa laporan Devidens Per Share, Earning Per Share dan Price Earning Ratioyang di peroleh dari situs resmi Bursa Efek Indonesia (www.idx.co.id).

\section{Analisis Data}

Metode analisis data yang digunakan pada penelitian ini menggunakan analisis regresi data panel. Data Panel merupakan gabungan antara time line dengan cross section (Vivekananda, 2019). Terdapat beberapa metode yang biasa digunakan dalam mengestimasi model regresi dengan data panel, diantaranya (Nandita dkk., 2019) :

a. Common effect Model

Common Effect Modelmerupakan pendekatan model data panel yang paling sederhana karena hanya mengkombinasikan data time series dan cross section. Pada model ini tidak diperhatikan dimensi waktu maupun individu, sehingga diasumsikan bahwa perilaku data perusahaan sama dalam berbagai kurun waktu. Metode ini bisa menggunakan pendekatan ordinary least square (OLS) atau teknik kuadrat terkecil untuk mengestimasi model data panel (Nandita dkk., 2019).

b. Fixed effect model

Fixed effect model adalah model dengan intercept berbeda untuk setiap subjek (cross section), tetapi slope setiap subjek tidak berubah seiring waktu. Model ini mengasumsikan bahwa intercept adalah berbeda setiap subjek sedangkan slope tetap sama antar subjek. Dalam membedakan satu subjek dengan subjek lainnya digunakan variabel dummy (Nandita dkk., 2019).

c. Random effect model

Random effect model adalah model dengan intercept berbeda untuk setiap subjek (cross section), tetapi slope setiap subjek tidak berubah seiring waktu. Model ini mengasumsikan bahwa intercept adalah berbeda setiap subjek sedangkan slope tetap sama antar subjek. Dalam membedakan satu subjek dengan subjek lainnya digunakan variabel dummy (Nandita dkk., 2019).

\section{HASIL DAN PEMBAHASAN}

Deviden Per Share (DPS) menunjukkan laba per lembar saham yang dibagikan kepada pemegang saham. Artinya jika nilai Deviden Per Share (DPS) naik maka akan meningkatkan nilai jual saham sehingga harga saham akan naik. Deviden Per Share (DPS) memiliki nilai probabilitas sebesar $0.0017<0.05$, maka Maka $\mathrm{H}_{0}$ ditolak dan $\mathrm{H}_{1}$ diterima, dapat disimpulkan bahwa variabel Deviden Per Share (DPS) berpengaruh signifikan terhadap harga saham. Laba per lembar saham mempengaruhi keputusan investor untuk membeli saham, semakin besar Deviden Per Share (DPS) maka akan semakin banyak minat para investor untuk membeli saham, dengan Deviden Per Share (DPS) yang tinggi akan mencerminkan bahwa perusahaan memiliki prospek yang baik karena dapat membayar deviden dengan jumlah yang tinggi, sehingga dapat menarik minat para investor untuk membeli saham perusahaan tersebut. 
Earning Per Share (EPS) menunjukkan laba untuk setiap lembar saham. Jika nilai Earning Per Share (EPS) tinggi maka perusahaan dapat memberikan tingkat kemakmuran terhadap pemegang saham. Earning Per Share (EPS) memiliki nilai probabilitas sebesar $0.0000<0.05$, maka $\mathrm{H}_{0}$ ditolak dan $\mathrm{H}_{1}$ diterima, dapat disimpulkan bahwa variabel Earning Per Share (EPS) berpengaruh signifikan terhadap harga saham. Nilai Earning Per Share (EPS) dapat mempengaruhi harga saham, semakin tinggi nilai Earning Per Share (EPS) maka peminat investor akan semakin banyak, pada dasarnya investor mengharapkan manfaat dari investasinya dalam bentuk laba. Jika nilai Earning Per Share (EPS) mengalami kenaikan sesuai dengan harapan investor, maka perubahan harga saham akan mengalami peningkatan seiring dengan minat investor untuk membeli saham tersebut.

Price Earning Ratio (PER) dapat mempermudah para analis saham dan investor dalam melakukan penilaian terhadap saham, nilai Price Earning Ratio (PER) yang kecil menunjukkan saham memiliki harga yang murah, sehingga dapat menarik para investor. Price Earning Ratio (PER) memiliki nilai probabilitas sebesar $0.4569>0.05$, Maka $\mathrm{H}_{0}$ diterima dan $\mathrm{H}_{1}$ ditolak, dapat disimpulkan bahwa variabel Price Earning Ratio (PER) tidak berpengaruh signifikan terhadap harga saham. Hal ini mengindikasikan bahwa Price Earning Ratio (PER) yang tinggi tidak berarti perusahaan mempunyai kinerja yang bagus untuk investasi, dimana Price Earning Ratio (PER) yang tinggi mengindikasikan harga saham sangat mahal dan tidak rasional (Mutiarani dkk., 2019). Investor cenderung membeli saham dengan nilai Price Earning Ratio (PER) yang lebih rendah, karena dengan Price Earning Ratio (PER) harga saham menjadi relatif murah dan wajar. Para investor melakukan investasi dengan membeli saham diharga murah dan nantinya akan dijual saat harga saham tinggi.

Earning Per Share (EPS) memiliki nilai koefisien tertinggi yaitu sebesar 4.742322, nilai koefisien Earning Per Share (EPS) lebih tinggi dibandingkan variabel bebas lainnya dan memiliki nilai probabilitas $0.0000<0.05$, dimana probabilitas tersebut paling terkecil dari variabel bebas lainnya dan berpengaruh terhadap pergerakan harga saham. Variable Earning Per Share (EPS) menjadi variabel yang sangat berpengaruh terhadap pergerakan harga saham, para investor pada dasarnya imengharapkan manfaat dari investasinya dalam bentuk laba bersih. Dimana variabel Earning Per Share (EPS) ini lebih mudah untuk dianalisa oleh para investor dan memiliki tingkat akurasi yang baik.

\section{SIMPULAN}

Dividend Per Share (DPS) memiliki nilai probabilitas sebesar $0.0017<0.05$, maka berpengaruh secara signifikan terhadap harga saham pada perusahaan manufaktur non BUMN yang terdaftar di Bursa Efek Indonesia. Laba per lembar saham mempengaruhi keputusan investor untuk membeli saham, semakin besar Deviden Per Share (DPS) maka akan semakin banyak minat para investor untuk membeli saham. Earning Per Share (EPS) memiliki nilai probabilitas sebesar $0.0000<0.05$, maka berpengaruh secara signifikan terhadap harga saham pada perusahaan manufaktur non BUMN yang terdaftar di Bursa Efek Indonesia. Nilai Earning Per Share (EPS) dapat mempengaruhi harga saham, semakin tinggi nilai Earning Per Share (EPS) maka peminat investor akan semakin banyak. Price Earning Ratio (PER) memiliki nilai probabilitas sebesar $0.4569>0.05$, maka tidak berpengaruh secara signifikan terhadap harga saham pada perusahaan 
manufaktur non BUMN yang terdaftar di Bursa Efek Indonesia. Hal ini mengindikasikan bahwa Price Earning Ratio (PER) yang tinggi tidak berarti perusahaan mempunyai kinerja yang bagus untuk investasi, dimana Price Earning Ratio (PER) yang tinggi mengindikasikan harga saham sangat mahal. Diantara variabel Dividend Per Share (DPS), Earning Per Share (EPS) dan Price Earning Ratio (PER), variabel Earning Per Share (EPS) yang berpengaruh dominan terhadap harga saham pada perusahaan manufaktur non BUMB yang terdaftar di Bursa Efek Indonesia. Earning Per Share (EPS) memiliki nilai koefisien tertinggi yaitu sebesar 4.742322, nilai koefisien Earning Per Share (EPS) lebih tinggi dibandingkan variabel bebas lainnya dan memiliki nilai probabilitas $0.0000<0.05$, dimana probabilitas tersebut paling terkecil dari variabel bebas lainnya dan berpengaruh terhadap pergerakan harga saham.

\section{DAFTAR PUSTAKA}

Arifian, Dini dan Hardi, Damyanti 2017, Pengaruh Earning Per Share Terhadap Harga Saham, The Asia Pacific Journal of Management Studies, Vol. 4, No. 2, 2017.

Desiana, Lidia 2017, Pengaruh Price Earning Ratio (PER), Earning Per Share (EPS), Devidend Yield Ratio (DYR), Dividend Payout Ratio (Dpr), Book Value Per Share (BVS) Dan Price Book Value (PBV) Terhadap Harga Saham Pada Perusahaan Subsektor Makanan Dan Minuman Yang Terdaftar Di Jakarta Islamic Index (JII), I-Finance, Vol. 3, No. 2, Desember 2017.

Junaeni, Irawati 2020, Pengaruh Indikator Keuangan Perusahaan Terhadap Harga Saham dalam Kelompok Jakarta Islamic Index, Riset dan Jurnal Akuntansi, Vol. 4, No. 1, Februari 2020.

Martha dan Meilin, Leviana 2018, Analisis Pengaruh Current Ratio (Cr), Debt To Equity Ratio (Der), Return On Assets (Roa), Dan Price To Earning Ratio (Per) terhadap Harga Saham pada Perusahaan Sektor Perkebunan Yang Terdaftar di Bursa Efek Indonesia Tahun 2010-2016, BILANCIA, Vol. 2, No. 4, Desember 2018.

Mutiarani, Niki Nony, Dewi, Riana dan Suhendro 2019, Pengaruh Price Earning Ratio, Price to Book Value, dan Inflasi Terhadap Harga Saham yang Terindeks IDX 30, Edunomika, Vol. 3, No. 2, Agustus 2019.

Nandita, Dea Aulia, Alamsyah, Lalu Bayu, Jati, Enggar Prima dan Widodo Edy 2019, Regresi Data Panel untuk Mengetahui Faktor - Faktor yang Mempengaruhi PDRB di Provinsi DIY Tahun 2011 - 2015, Indonesian Journal of Applied Statistics, Vol. 2, No. 1, May 2019

Putra, Ariswandi sang 2018, Pengaruh Earning Per Share (Eps), Dividend Per Share (Dps) Dan Financial Leverage (Fl) Terhadap Harga Saham Perusahaan Manufaktur di Bursa Efek Indonesia, Jurnal Pendidikan Ekonomi Fakultas Ekonomi, Vol. 1, No. 1, Maret 2018. 
Rahmadewi, Pande Widya dan Abundanti, Nyoman 2018, Pengaruh EPS, PER, CR dan ROE Terhadap Harga Saham di Bursa Efek Indonesia, E-Jurnal Manajemen Unud, Vol. 7, No. 4, 2018.

Reke, James Sylvanus Uly 2020, Analisis Pengaruh Kinerja Keuangan Perusahaan Terhadap Dividend Per Share, Jurnal Maneksi, Vol 9, No. 1, Juni 2020.

Sanjaya, Sigit dan Afriyenis, Winda 2018, Analisis Fundamental Terhadap Harga Saham Perusahaan Manufaktur Sektor Industri Barang Konsumi, Jurnal Kajian Ekonomi Islam, Vol. 3, No. 1, Januari - Juni 2018.

Tiara, Seny, Malikah, Anik dan Hariri 2020, Pengaruh Earning Per Share (EPS), Dividend Per Share (DPS) dan Return On Equity (ROE) Terhadap Harga Saham, E-JRA, Vol. 09, No. 03, Agustus 2020. 


\section{Lampiran 1. Random Effect Model}

Dependent Variable: Y

Method: Panel EGLS (Cross-section random effects)

Date: 06/02/21 Time: 17:55

Sample: 20152019

Periods included: 5

Cross-sections included: 20

Total panel (balanced) observations: 100

Swamy and Arora estimator of component variances

\begin{tabular}{lllll}
\hline Variable & Coefficient & Std. Error & t-Statistic & Prob. \\
\hline C & 2967.574 & 536.8975 & 5.527264 & 0.0000 \\
X1 & -4.240146 & 1.310548 & -3.235400 & 0.0017 \\
X2 & 4.742322 & 0.864074 & 5.488331 & 0.0000 \\
X3 & -0.540829 & 0.723967 & -0.747035 & 0.4569
\end{tabular}

Effects Specification

Cross-section random

S.D. Rho

Idiosyncratic random

Weighted Statistics

R-squared

0.256218

Mean dependent var

1529.789

Adjusted R-squared

0.232975

S.D. dependent var

2172.056

S.E. of regression

1902.286

Sum squared resid

$3.47 \mathrm{E}+08$

F-statistic

11.02336

Durbin-Watson stat

0.678527

Prob(F-statistic) $\quad 0.000003$

Unweighted Statistics

R-squared

0.291158

Mean dependent var

3992.480

Sum squared resid $7.62 \mathrm{E}+08$

Durbin-Watson stat 0.309508

Sumber : Output Eviews 9 (2021) 